\title{
Tokarczuk dla wszystkich Adaptacja tekstu prozatorskiego do nauczania języka polskiego jako obcego na niższych poziomach zaawansowania
}

\author{
Tokarczuk for everyone \\ How to adapt literary texts in teaching Polish as a foreign language \\ to low-level students
}

\begin{abstract}
Elżbieta Koziołkiewicz's aim in this article is to examine methods of including prose fiction in lessons of Polish as a foreign language offered to low-level students (up to B1 level). In the first part, Koziołkiewicz reviews available didactic materials and theoretical publications devoted to the topic of literature in foreign language teaching. On this basis, she formulates some general rules as regards the criteria for selecting literary texts, namely: the need to use contemporary fiction that is potentially accessible thanks to the inclusion of universal themes and, as far as possible, realities. She goes on to stress the need to adapt the original texts and puts her discussion in the context of other research articles dedicated to this issue. The second part of the article has been devised as a practical guide to adaptation. The text chosen as a sample in this case study is the short story "Pasażer" ("The Passenger") by Olga Tokarczuk, published in the collection Opowiadania bizarne. Koziołkiewicz shows how the scope of interferences can be limited to necessary changes and highlights the use of internationalisms and synonyms. She points to the benefits of using multiple simplified versions of an original text in class.
\end{abstract}

Keywords: adaptation, Olga Tokarczuk, Polish literature as foreign literature, low-level students learning Polish as a foreign language, teaching materials, Polish language pedagogy 


\section{Literatura w nauczaniu języka polskiego jako obcego Uwagi wstępne}

Pozycja dzieł literackich we współczesnej glottodydaktyce polonistycznej — zarówno w refleksji badawczej, jak i w praktyce — jest ugruntowana. Lektorzy pragnący wykorzystać $\mathrm{w}$ nauczaniu utwory polskich pisarzy dysponują publikacjami przedstawiającymi ogólne zasady doboru i użycia tekstów ${ }^{1}$ oraz scenariuszami konkretnych zajęć zaplanowanych najczęściej wokół wiersza albo krótkiego opowiadania ${ }^{2}$. Utwory literackie lub ich fragmenty znajdują się nie tylko w osobnych antologiach (niestety, wciąż nielicznych) ${ }^{3}$, lecz także w podręcznikach, również kursowych, przeznaczonych do pogłębiania ogólnej znajomości języka ${ }^{4}$.

${ }^{1}$ A. Seretny: Tekst literacki $w$ dydaktyce języka polskiego jako obcego. Między percepcja a recepcja dzieła. W: Literatura polska w świecie. Zagadnienia recepcji i odbioru. Red. R. Cudak. Wydawnictwo Gnome, Katowice 2006, s. 292-306; M. Cyzman: Czego jeszcze nie wiemy o nauczaniu literatury polskiej? Tekst literacki na lekcji języka polskiego jako obcego. „Teraźniejszość — Człowiek — Edukacja" 2011, nr 4, s. 91-101 (tu obszerna bibliografia); T. Czerkies: Rozwijanie kompetencji literackiej - teksty prozatorskie na zajęciach języka polskiego jako obcego. W: W poszukiwaniu nowych rozwiazań. Dydaktyka języka polskiego jako obcego u progu XXI wieku. Red. W.T. Miodunka, A. Seretny. Wydawnictwo Uniwersytetu Jagiellońskiego, Kraków 2008, s. 255-263.

${ }^{2}$ Na przykład: Literatura i glottodydaktyka $w$ praktyce. Tekst literacki $w$ nauczaniu języka polskiego jako obcego. Red. A. Kwiatkowska, M. Válkova Maciejewska. Współpraca K. Tyrakowska, I. Skrzypczak. Wydawnictwo „Poznańskie Studia Polonistyczne”, Poznań 2018; B. Szałasta-Rogowska: Tekst literacki i malarski w nauczaniu cudzoziemców. Sposoby pracy na zajęciach lektoratowych. W: Sztuka czy rzemiosło? Nauczyć Polski i polskiego. Red. A. Achtelik, J. Tambor. Wyd. 2. Gnome - Wydawnictwa Naukowe i Artystyczne, Katowice 2009, s. 141152. Zob. też przypis 10 , gdzie wskazano publikacje poświęcone wykorzystaniu poezji.

${ }^{3}$ Antologia bajek, baśni, legend $i$ opowiadań z zadaniami. Wybór i oprac. A. Dunin-Dudkowska, A. Trześniewska-Nowak. Ilustracje na okładce i w tekście K. Wójcik. Wydawnictwo Uniwersytetu Marii Curie-Skłodowskiej, Lublin 2020. Publikację skierowano przede wszystkim do dzieci polonijnych, ale można wybrać z niej fragmenty, które sprawdzą się też w pracy z innymi odbiorcami (na przykład legendy). Tylko legendy znalazły się w wyborze tekstów wydanym przez Muzeum Warszawy: K. Žák-Caplot: Legendy Starego Miasta w Warszawie. Wybór tekstów do nauki języka polskiego jako obcego z ćwiczeniami. Muzeum Warszawy, Warszawa 2019. W tej książce znajdują się wersje legend $\mathrm{w}$ adaptacjach przeznaczonych do nauki języka polskiego na trzech głównych poziomach zaawansowania (A, B, C).

${ }^{4}$ E. Zarych: Przejdź na wyższy poziom. Język polski dla obcokrajowców. Poziom B2/C1. Wydawnictwo Nowela, Poznań 2014; Eadem: Język kluczem do kraju. Język polski dla obcokrajowców. Poziom C1/C2. Nowela - Portal romanisty, Poznań 2018. (Opowiadania Sławomira Mrożka, które dla zaawansowanych studentów polecają również inni glottodydaktycy zob. np. W.P. Turek: Utwory prozaiczne Stawomira Mrożka jako teksty wykorzystywane w nauczaniu gramatyki, stylistyki i kultury języka polskiego jako obcego. „Acta Universitatis Lodziensis. Kształcenie Polonistyczne Cudzoziemców” 2010, T. 17, s. 433-438. Pobrano z: https:// 
Z bardziej szczegółowego przeglądu propozycji tekstów literackich do nauczania języka polskiego wynika jednak, że różne grupy uczących się (na różnych poziomach zaawansowania) nie mają takiego samego dostępu do materiałów. Zdecydowana większość konspektów lekcji czy opracowań adresowana jest do studentów na wyższych poziomach nauczania (zwykle od B2, wyjątkowo od B1.2 w górę) $)^{5}$ Naturalnie, obcowanie z literaturą jest szczególnie satysfakcjonujące dla studentów znających język w stopniu zaawansowanym i zainteresowanych polszczyzną także jako językiem kultury, a nie wyłącznie narzędziem codziennej komunikacji. Badacze podkreślają jednak wagę włączania utworów literackich również do programów kursów dla początkujących ${ }^{6}$, a refleksje teoretyczne w tym obszarze znajdują potwierdzenie w pozycjach oferowanych przez wydawnictwa językowe. Ukazywanie się kolejnych tomików krótkich opowiadań zredagowanych specjalnie dla osób pobierających naukę na poziomach $\mathrm{A} 0-\mathrm{A} 2^{7}$ dowodzi, że studenci zaczynający przygodę z polskim szukają fikcjonalnych narracji urozmaicających naukę. Wydawanie dla tej najliczniejszej grupy uczących się nowych, motywujących pomocy dydaktycznych, opartych na tekstach polskich autorów, wypełniłoby lukę w zasobach edukacyjnych.

dspace.uni.lodz.pl/xmlui/handle/11089/9604 [11.08.2021]) — poezję Jana Brzechwy, Adama Mickiewicza, Juliana Tuwima, Stanisława Grochowiaka — zob. R. Ciesielska-Musameh, B. Guziuk-Świca, G. Przechodzka: Z polskim w świat. Podręcznik do nauki języka polskiego jako obcego. Cz. 1: Poziom B1/B2. Wyd. 3. Wydawnictwo Uniwersytetu Marii Curie-Skłodowskiej, Lublin 2018; Eaedem: Z polskim w świat. Podręcznik do nauki języka polskiego jako obcego. Cz. 2: Poziom B1/B2. Wydawnictwo Uniwersytetu Marii Curie-Skłodowskiej, Lublin 2019. Por. też M. Świstowska: Obecność tekstów prozy polskiej po 1989 r. w nauczaniu języka polskiego jako obcego - realia, potrzeby, problem wyboru. „Acta Universitatis Lodziensis. Kształcenie Polonistyczne Cudzoziemców" 2010, T. 17, s. 426-427. Pobrano z: https://bazhum.muzhp.pl/media/ files/Acta_Universitatis_Lodziensis_Ksztalcenie_Polonistyczne_Cudzoziemcow/Acta_Universitatis_Lodziensis_Ksztalcenie_Polonistyczne_Cudzoziemcow-r2010-t17/Acta_Universitatis_Lodziensis_Ksztalcenie_Polonistyczne_Cudzoziemcow-r2010-t17-s425-432/Acta_Universitatis Lodziensis_Ksztalcenie_Polonistyczne_Cudzoziemcow-r2010-t17-s425-432.pdf [11.08.2021] (tu informacje o zawartości podręczników wydanych przed 2008 rokiem).

5 T. Czerkies: Tekst literacki w nauczaniu języka polskiego jako obcego (z elementami pedagogiki dyskursywnej). Księgarnia Akademicka, Kraków 2012; Eadem: Literackie lustro kultury. Literatura polska w ćwiczeniach dla obcokrajowców. Poziom B.1.2-C.1. Wydawnictwo Avalon, Kraków 2019.

${ }^{6}$ W. Miodunka et al.: Nauczanie i promocja języka polskiego w świecie. Diagnoza, stan, perspektywy. Wydawnictwo Uniwersytetu Śląskiego, Katowice 2018, s. 294; A. Seretny: Tekst literacki w dydaktyce języka polskiego jako obcego..., s. 297, 300.

7 J. Bednarek, A. Swatek: Learn Polish Through Stories. Centrum Języków Obcych Inspiration, Wrocław 2018; M. Hiszpańska: Ola. Czytanka do nauki polskiego dla cudzoziemców na poziomie A2-B1. Studio Anatta, Warszawa 2019; B.K. Jędryka: Walizka. Wydawnictwo Polish Point — Translator, Warszawa 2016; A. Stelmach: Czytaj krok po kroku. Proste historie. [T.] 1-3. Glossa, Polish Language School, Kraków 2018-2019. 
Jak wynika z artykułu Tamary Czerkies, większość studentów uczących się języka polskiego jako obcego ${ }^{8}(65 \%)$ woli czytać w języku rodzimym prozę niż poezję. Odpowiedzi ankietowanych są zgodne w tym zakresie z intuicją autorki badań, jednej ze specjalistek w dziedzinie wykorzystania utworów literackich w nauczaniu języka polskiego jako obcego' ${ }^{9}$, potwierdzają też niesłabnącą dominację powieści w szeroko pojętej kulturze zachodniej. Rozpoznania Czerkies zachęcają do zwiększenia udziału tekstów prozatorskich w materiałach glottodydaktycznych, w których poezja jest już bardzo dobrze reprezentowana ${ }^{10}$. Do jej popularności przyczynia się niewątpliwie niewielka objętość wierszy oraz możliwość wybrania stosunkowo łatwych językowo przykładów z dorobku najsłynniejszych polskich twórców, w tym noblistów - Wisławy Szymborskiej i Czesława Miłosza. Poezja najprawdopodobniej nie jest jednak pierwszym wyborem lekturowym uczestników kursu (w badaniach Czerkies jako ulubiony rodzaj literacki wskazało ją 15\% respondentów), warto więc rozważyć wykorzystanie w nauczaniu języka opowiadań lub fragmentów powieści. W pracy z grupami początkującymi zaproponowanie (statystycznie) chętniej czytanej prozy pozwoli uniknąć dodatkowego wyzwania, jakim mogłaby okazać się dla nieprzywykłych do poezji odbiorców konfrontacja $\mathrm{z}$ wierszem.

\section{Czytaj po polsku — proza dla początkujących?}

Realizację postulatów - posłużenie się tekstem prozatorskim w nauczaniu języka polskiego jako obcego i opracowanie takiego tekstu dla uczących się na

${ }^{8}$ Badania przeprowadzono w dziesięciu polskich ośrodkach i jednym zagranicznym. T. Czerkies: Wykorzystanie tekstu literackiego na zajęciach języka polskiego jako obcego (motywy $i$ oczekiwania studentów). „Acta Universitatis Lodziensis. Kształcenie Polonistyczne Cudzoziemców" 2011, T. 18, s. 113-114. Pobrano z: https://dspace.uni.lodz.pl/xmlui/bitstream/ handle/11089/9287/13-czerkies.pdf?sequence=1\&isAllowed=y [11.08.2021].

${ }^{9}$ Błędne okazało się jednak wstępne założenie, że czytelnikami poezji są przede wszystkimi reprezentanci narodów słowiańskich. Ibidem, s. 125.

${ }^{10}$ Wybrane pozycje literaturowe: W. Próchniak: Klucz do wierszy. Poezja w nauczaniu języka polskiego jako obcego. Wydawnictwo KUL, Lublin 2012; N. Tsai: Utwór poetycki jako tekst glottodydaktyczny. Uniwersytet Lódzki. Wydział Filologiczny. Katedra Lingwistyki Stosowanej i Kulturowej. Łódź 2012. Niepublikowana rozprawa doktorska; Eadem: Czarno na białym Poezja konkretna na zajęciach językowych. „Acta Universitatis Lodziensis. Kształcenie Polonistyczne Cudzoziemców" 2013, T. 20, s. 329-338. Pobrano z: https://dspace.uni.lodz.pl/xmlui/handle/11089/4472 [11.08.2021]; E. Jaskółowa: Poezja w nauczaniu języka polskiego jako obcego. W: Sztuka czy rzemiosto?..., s. 125-140. 
poziomach A1/A2 - B1 — zapewniają wybrane pozycje ${ }^{11}$ Czytaj po polsku wydawane przez Szkołę Języka i Kultury Polskiej Uniwersytetu Śląskiego. Pierwsze cztery tomiki serii, opatrzone podtytułem Edycja dla poczatkujacych, to opracowania dziewiętnastowiecznych nowelek; kolejno Kamizelki i Z legend dawnego Egiptu Bolesława Prusa (poziom A1/A2), Latarnika i Janka Muzykanta Henryka Sienkiewicza (A2/B1), a także utworów Marii Konopnickiej ( $\mathrm{Na}$ sza szkapa), Elizy Orzeszkowej (Dobra pani) i Stefana Żeromskiego (Siłaczka, Rozdziobia nas kruki, wrony...) — nowele Konopnickiej, Orzeszkowej i Żeromskiego dostosowano do poziomu A2. W 2020 roku w serii ukazała się adaptacja Gloria victis Orzeszkowej (A1/A2) ${ }^{12}$. Ze względu na archaiczny język nowel ich teksty poddano głębokim modyfikacjom, w których wyniku uzyskano bardzo odległe od oryginałów streszczenia kluczowych zdarzeń. Porównanie obu wersji: oryginału i tekstu opracowanego, oraz dostrzeżenie ingerencji niezbędnych do przystosowania nowelki dla początkującego odbiorcy unaocznia mu jego nieznajomość języka (cudzoziemiec może być przy tym nieświadomy, w jakim stopniu język oryginału jest niedzisiejszy i nieprzystępny również dla wielu rodzimych użytkowników polszczyzny). Jeżeli lektura utworu literackiego ma dawać studentom nie tylko przyjemność obcowania z fabułą, lecz także satysfakcję z przyswajania złożonego komunikatu o funkcji estetycznej, to potencjalna konfrontacja z pierwowzorem adaptacji nie powinna budzić w uczącym się poczucia, że niezależnie od postępów w nauce wciąż jest on gotowy jedynie do pracy z bardzo uproszczonym ,brykiem”.

Niespełna połowa uczestników badań Czerkies (44\%) wskazała wzbogacanie słownictwa jako motywację do czytania literatury polskiej ${ }^{13}$. Choć dziewiętnastowieczna nowelistyka obfituje w nowe dla uczących się wyrazy, ze względu na to, że opisują one dawne realia, często jest nieodpowiednia dla studentów wskazanych jako odbiorcy danej adaptacji ${ }^{14}$ (przykładowo, wśród słów uwzględnionych w ,przygotowaniu do lektury” dwóch tekstów Żeromskiego znajdują się: sołtys, znachor, tyfus, szlachcic, bagnet ${ }^{15}$ ). Drugim celem lektury

${ }^{11}$ Pozostałe przeznaczono dla uczących się na bardziej zaawansowanych poziomach.

${ }_{12} \mathrm{~W}$ tym tomiku zastosowano odmienne niż we wcześniejszych reguły adaptacji — zachowano o wiele więcej oryginalnego tekstu. To podejście bliższe jest rozwiązaniom postulowanym przeze mnie w drugiej części artykułu.

13 T. Czerkies: Wykorzystanie tekstu literackiego na zajęciach języka polskiego jako obcego..., s. 126.

${ }^{14} \mathrm{O}$ pozornej łatwości (fabularnej) i skomplikowaniu językowym nowelek pozytywistycznych wspomina też Róża Ciesielska-Musameh: Literatura w nauczaniu cudzoziemców. Poradnik metodyczny. Część druga: Praca z tekstem literackim na zajęciach językowych. http://docplayer. pl/39455545-Literatura-w-nauczaniu-cudzoziemcow.html [dostęp: 3.02.2021].

${ }^{15}$ S. Żeromski: Siłaczka. Rozdziobia nas kruki, wrony... [Opowiedziała i oprac. A. Szol. Red. nauk. R. Cudak, W. Hajduk-Gawron, J. Tambor]. Wyd. 3. [Czytaj po polsku. T. 4]. Wydawnictwo Uniwersytetu Śląskiego, Katowice 2013, s. 13, 25. 
polskich tekstów literackich wymienianym przez ankietowanych studentów (35\%) było lepsze poznanie polskiej kultury. Niewątpliwie pierwsze utwory wydawane w ramach Czytaj po polsku przybliżają odbiorcy wybrane idee i motywy polskiego pozytywizmu. Rodzi się jednak pytanie, na ile wiedza ta pozwala cudzoziemcowi uczącemu się na poziomie A2/B1 pełniej uczestniczyć w kulturze poza kontekstem lekcyjnym. Jedna z redaktorek serii, Wioletta Hajduk-Gawron, w artykule prezentującym przygotowane na Uniwersytecie Śląskim materiały wspominała o niechęci polskich uczniów do literatury dawnej, którą powinni obowiązkowo przeczytać: „szczególnie młodzież traktuje kanon lektur szkolnych jako zło konieczne (chodzi zwłaszcza o teksty starsze), próbując przy tym »bezboleśnie« przebrnąć przez opasłe tomiska. Stąd też rośnie sprzedaż bryków"16. Nie ma powodu, by w tym miejscu omawiać samo zjawisko produkcji streszczeń. Należy jedynie wskazać istotną dla nas konsekwencję: oczytany w adaptacjach dziewiętnastowiecznej nowelistyki uczestnik kursu języka polskiego prawdopodobnie nie znajdzie okazji, by porozmawiać o swoich lekturowych wrażeniach ze znajomymi Polakami. Ta część polskiej klasyki nie przemawia dziś do publiczności literackiej i zapoznanie się z tymi tekstami nie zapewnia uczestnictwa $\mathrm{w}$ autentycznej wymianie doświadczeń lekturowych z innymi czytelnikami ${ }^{17}$. W kolejnych pracach Hajduk-Gawron wypowiadała się o konieczności zróżnicowania oferty lekturowej adresowanej do cudzoziemców: „być może (wreszcie) istnieje taka potrzeba, na użytek odbiorców zewnętrznych kulturowo, stworzenia kanonu alternatywnego. Takiego, który gwarantowałby dotarcie do dobrej literatury, ale niekoniecznie tej mesjanistycznej i pozy tywistycznej”" ${ }^{18}$, oraz: „warto czasem zrezygnować z powszechnie cenionych w Polsce arcydzieł na rzecz utworów mniej reprezentatywnych dla kultury polskiej, a zawierających treści uniwersalne" ${ }^{19}$. W tym kontekście

${ }^{16}$ W. Hajduk-Gawron: „Czytaj po polsku” - czytanie jako jedna z możliwości poszerzania kompetencji językowych [O serii „,Czytaj po polsku”, Katowice 2003, 2004]. „Postscriptum” 2004, nr 1, s. 53. Pobrano z: https://bazhum.muzhp.pl/media//files/Postscriptum/Postscriptum -r2004-t-n1(47)/Postscriptum-r2004-t-n1(47)-s53-63/Postscriptum-r2004-t-n1(47)-s53-63.pdf [11.08.2021].

${ }^{17}$ Problem ten szeroko komentują, omawiając aktualny status poszczególnych twórców, Emilia Kubicka i Marzena Cyzman w tekście: Seria „Czytaj po polsku”. Ikony literatury polskiej? W: Nowe perspektywy w nauczaniu języka polskiego jako obcego. 3. Red. E. Kubicka, A. Walkiewicz. Wydawnictwo Naukowe Uniwersytetu Mikołaja Kopernika, Toruń 2015, s. 173-191.

${ }^{18}$ W. Hajduk-Gawron: Lektura obowiązowa i co ponadto? O obecności i nieobecności literatury polskiej poza krajem. W: Literatura polska w świecie. Zagadnienia recepcji i odbioru..., s. 33.

${ }^{19}$ W. Hajduk-Gawron: Arcydzieła literatury polskiej w praktyce glottodydaktycznej. Zaadaptować czytelnika i tekst. W: Adaptacje. [T.] 1: Język - literatura - sztuka. Red. W. Hajduk-Gawron, A. Madeja. [Biblioteka Postscriptum Polonistycznego. Nr 3]. Uniwersytet Śląski w Katowicach. Szkoła Języka i Kultury Polskiej. Katedra Międzynarodowych Studiów PolskichWydawnictwo Gnome, Katowice 2013, s. 364. 
opublikowanie Gloria victis jako najnowszego tomu Czytaj po polsku jest jednak nieoczekiwanym powrotem do przyjętego na początku wydawania serii klucza doboru tytułów.

W rozważaniach nad wprowadzaniem literatury polskiej do programów ogólnych kursów językowych pojawiają się wątpliwości dotyczące jej dostępności dla odbiorców zewnętrznych kulturowo ${ }^{20}$. Hajduk-Gawron określiła literaturę polską następującymi przymiotnikami: „hermetyczna, trudna, czasem smutna, upolityczniona"21. W artykule z 2011 roku Marzena Cyzman przypomniała opinie o hermetyczności polskich utworów i sugestie, że znajomość kontekstu społeczno-historyczno-politycznego jest nieodzowna przy ich lekturze ${ }^{22}$. W późniejszym szkicu, napisanym wspólnie z Emilią Kubicką, Cyzman trafnie wskazała, że wizja literatury częściowo odziedziczona przez rodzimą glottodydaktykę ukształtowana została pod wpływem dość schematycznego myślenia o procesach historycznoliterackich ${ }^{23}$. Dodatkowo funkcjonują tu chyba podwójne standardy — odmienne w stosunku do poezji i prozy. Skoro możemy wybrać, przykładowo, uniwersalne w swym przesłaniu wiersze Szymborskiej zamiast dawnej poezji patriotycznej, dlaczego nie zastosować analogicznych kryteriów wyboru w pracy z epiką? Opublikowane w ramach Czytaj po polsku nowelki, zwłaszcza postrzegane jako mikroantologia, a nie osobne teksty, moga zniechęcić początkującego studenta przygnębiającą treścią, w której powtarzające się motywy literackie to nędza i śmierć.

\section{Współczesna, uniwersalna, zaadaptowana}

O stworzenie bardziej zrównoważonej listy propozycji lekturowych dla studentów języka polskiego jako obcego apelują autorzy publikacji Nauczanie i promocja języka polskiego ws świecie. Diagnoza, stan, perspektywy:

Działaniom nakierowanym na poznawanie [...] literatury [...] podejmującej często problematykę patriotyczną powinna towarzyszyć promocja lektury tekstów literackich, które prowokują do odczytań w „tu i teraz”

${ }^{20}$ Korzystam tu z terminu ukutego przez Hajduk-Gawron: Lektura obowiazkowa i co ponadto? ..., s. 33. Na ten temat zob. też M. Świstowska: Obecność tekstów prozy polskiej po 1989 r. w nauczaniu języka polskiego jako obcego..., s. 428-429.

${ }^{21}$ W. Hajduk-Gawron: Arcydzieła literatury polskiej w praktyce glottodydaktycznej..., s. 364.

${ }_{22}^{2}$ M. Cyzman: Czego jeszcze nie wiemy o nauczaniu literatury polskiej? ..., s. 92-93.

${ }^{23}$ E. Kubicka, M. Cyzman: Seria „,Czytaj po polsku”..., s. 181-183. 


\section{czytelników i których polskość zaznacza się przede wszystkim w tym, że ich autorami są pisarze polscy ${ }^{24}$.}

Postulują również tworzenie nowych serii adaptacji tekstów literackich oraz antologii dla uczniów szkół podstawowych i średnich. Nie ulega wątpliwości, że dla studentów na poziomie A1-A2 opowiadanie czy fragment powieści muszą być znacząco uproszczone. Podsumujmy zatem najważniejsze ustalenia polskich glottodydaktyków na temat technik adaptacyjnych stosowanych w opracowaniu tekstu literackiego do wykorzystania w nauczaniu języka polskiego jako obcego.

Początkowy etap adaptacji utworu literackiego to wybór tytułu, który zaproponujemy studentom; wskazówki szczególnie użyteczne w przypadku adaptacji prozy oferują Anna Seretny i Tamara Czerkies ${ }^{25}$. Romuald Cudak i Wioletta Hajduk-Gawron idą za rozpoznaniami Aleksandra Kozłowskiego i charakteryzują adaptację sensu largo oraz sensu stricto. Pierwsza oznacza okołotekstową pracę związaną z selekcją materiału oraz opatrzeniem utworu definicjami i wyjaśnieniami niezbędnymi do jego zrozumienia. Na poziomie A1-A2 adaptacja taka okaże się prawdopodobnie niewystarczająca, ale należy zauważyć, że analogiczną metodę stosują autorzy preparowanych opowiadanek związanych fabularnie z podręcznikiem Polski krok po kroku i dopasowanych tematycznie do prezentowanego w nim materiału. Teksty są konstruowane $\mathrm{z}$ wykorzystaniem słownictwa i struktur gramatycznych z konkretnych lekcji (selekcja) oraz opatrzone na marginesach stron tłumaczeniami nowych słów na angielski. Adaptacja sensu stricto to wszystkie wewnątrztekstowe ingerencje - skróty, pominięcia (adaptacja eliminująca) oraz parafrazy i uproszczenia (adaptacja modyfikująca). W cytowanym szkicu Cudak i Hajduk-Gawron wskazują kilka przykładów obu typów adaptacji w pozycjach Czytaj po polsku ${ }^{26}$.

Cennych inspiracji w pracy nad adaptacją tekstu literackiego do nauczania języka polskiego jako obcego może dostarczyć opis adaptacji przygotowywanych na potrzeby spektakli teatralnych wystawianych przez studentów letniej szkoły języka, literatury i kultury polskiej w Cieszynie. Odpowiedzialna za scenariusze i reżyserię Maria Wacławek nie tylko prezentuje pomysłowe rozwiązania sceniczne, lecz także objaśnia sposoby pracy z tekstem, które można zastosować również do adaptacji utworów przeznaczonych do adaptacji lektury,

${ }^{24}$ W. Miodunka et al.: Nauczanie i promocja języka polskiego w świecie..., s. 296, podkr. - E.K.

${ }^{25}$ A. Seretny: Tekst literacki $w$ dydaktyce języka polskiego jako obcego..., s. 298-301; T. Czerkies: Rozwijanie kompetencji literackiej - teksty prozatorskie na zajęciach języka polskiego jako obcego..., s. 258-262.

${ }^{26}$ R. Cudak, W. Hajduk-Gawron: Problematyka adaptacji tekstu w edukacji literackiej cudzoziemców. W: Edukacja polonistyczna jako zobowiazanie: powszechność i elitarność polonistyki. Red. E. Jaskółowa et al., przy współpracy D. Jagodzińskiej i A. Zok-Smoły. T. 1. Wydawnictwo Uniwersytetu Śląskiego, Katowice 2016, s. 607-614. 
a nie inscenizacji ${ }^{27}$. Dla początkujących lektorów języka polskiego pomocny może też okazać się artykuł Pauli Góralczyk-Mowczan i Mateusza Gazego, poświęcony przygotowaniu adaptacji tekstów na poziom A1 ${ }^{28}$. Autorzy artykułu wskazują w nim między innymi formy gramatyczne, jakie należy wyeliminować $\mathrm{z}$ adaptacji, ale zbyt dużo miejsca poświęcają krytyce nieudolnych prób adaptacji przygotowanych przez studentów glottodydaktyki — przyszłych nauczycieli i nie przedstawiają pozytywnych wzorców. Ponadto nie komentują w żaden sposób własnego wyboru adaptowanego opowiadania - Mantylki Mirosława Żuławskiego. Utwór jest zabawny i nieskomplikowany, ale zawiera stereotypową wizję polskiej rodziny (sfrustrowana kobieta nieradząca sobie z dziećmi, nieempatyczny mężczyzna zainteresowany bardziej polityką niż rodziną), wizję, którą rozsądniej byłoby z materiałów edukacyjnych raczej rugować niż powielać jej kolejne wcielenia. Internacjonalizm w tytule opowiadania przemawiałby za jego użyciem, gdyby tylko słowo to nie było nieużywanym już dziś zupełnie archaizmem.

Jakie teksty prozatorskie należałoby zatem adaptować $\mathrm{z}$ przeznaczeniem do nauki polskiego dla początkujących? Badacze zgodnie wspominają o konieczności zainteresowania czytelnika treścią i zbudowania relacji między nim a czytanym utworem ${ }^{29}$, pożądane jest więc użycie narracji potencjalnie bliskiej doświadczeniom studentów ${ }^{30}$. $Z$ tego względu najodpowiedniejsze wydają się opowiadania i fragmenty powieści współczesnych, w których czas akcji i powstania są mniej więcej zbieżne. Ogranicza to na wstępie problem niezrozumiałych realiów tekstu i przestarzałej leksyki ${ }^{31}$. Jeżeli pracujemy z grupą jednojęzyczną, warto sprawdzić, czy w kraju pochodzenia studentów wydano jakąś książkę autora, którego tekst zamierzamy z nimi przeczytać. Nawet jeżeli nigdy wcześniej o danym twórcy nie słyszeli, fakt, że wzbudza on pewne zainteresowanie wśród ich rodaków, może pobudzić ciekawośćc ${ }^{32}$. Na rozpoznawalność pisarzy wpływają też naturalnie nagrody literackie, szczególnie prestiżowe,

${ }^{27}$ M. Wacławek: Od adaptacji do spektaklu na motywach dzieła $-z$ doświadczeń glottodydaktycznych. „Annales Universitatis Mariae Curie-Sklodowska. Sectio N - Educatio Nova” 2020, vol. 5, s. 409-425. https://doi.org/10.17951/en.2020.5.409-425.

${ }^{28}$ P. Góralczyk-Mowczan, M. Gaze: Btędy w adaptacjach tekstów literackich (na podstawie prac studentów specjalizacji Nauczanie Języka Polskiego jako Obcego). „Acta Universitatis Lodziensis. Kształcenie Polonistyczne Cudzoziemców" 2015, T. 22, s. 237-249. https://doi. org/10.18778/0860-6587.22.16.

${ }^{29}$ K. Frukacz: Reportaż literacki w glottodydaktyce polonistycznej — prolegomena. „Kwartalnik Polonicum" 2018, nr 28/29, s. 36.

${ }^{30}$ A. Seretny: Tekst literacki w dydaktyce języka polskiego jako obcego..., s. 299-300.

${ }^{31}$ Zbliżony postulat formułuje A. Seretny - ibidem, s. 301.

${ }^{32}$ Ogólne trendy w publikowaniu literatury polskiej za granicą przedstawia W. Hajduk-Gawron: Przektady literatury polskiej a dobór tekstów literackich w nauczaniu cudzoziemców. W: Sztuka czy rzemiosto?..., s. 153-161. Autorka odnosi się między innymi do wpływu nagród na pozycję pisarza na obcym rynku wydawniczym (s. 156). 
gdyż z reguły kojarzone są one nawet przez osoby, które na co dzień nie śledzą wiadomości ze świata kultury.

Glottodydaktycy rekomendowali prozę Olgi Tokarczuk jako źródło materiałów edukacyjnych jeszcze przed jej noblowskim sukcesem ${ }^{33}$. Jako autorka wyróżniona wcześniej innymi polskimi i zagranicznymi nagrodami Tokarczuk może być czytelnikom znana przynajmniej ze słyszenia, istnieje też szansa, że w rodzimym języku uczących się opublikowano przekłady tekstów pisarki. Za czytaniem utworów Tokarczuk z cudzoziemcami najmocniej przemawia jednak charakter jej twórczości. Jak stwierdza Lidia Tanuszewska: „Autorka podejmuje tematy uniwersalne, tworząc obraz świata, który jest tak samo bliski i równocześnie tak samo daleki Polakom, Amerykanom, Chińczykom, Argentyńczykom czy Macedończykom"34.

\section{Studium przypadku: Pasażer}

W tej części artykułu przedstawione i skomentowane zostaną kolejne etapy adaptacji opowiadania Pasażer zaczerpniętego z Opowiadań bizarnych Olgi Tokarczuk ${ }^{35}$. Różne wersje tekstu bardzo dobrze sprawdziły się w pracy z dorosłymi uczestnikami lektoratu języka polskiego oraz dziećmi uczęszczającymi na lekcje w sobotniej szkole polskiej. Założenia, którymi kierowałam się w przygotowaniu adaptacji, można zastosować, po ewentualnych modyfikacjach, do opracowania dowolnego fragmentu prozy.

\section{Kryteria wyboru tekstu}

Pasażer to krótka (826 słów), jednowątkowa fabuła o wyraźnej ramie kompozycyjnej: narrator relacjonuje historię zasłyszaną od osoby zajmującej sąsiednie miejsce w samolocie. Tematem opowieści są wydarzenia i stany uczuciowe przeżywane przez współpasażera narratora w dzieciństwie, dzięki czemu tekst

${ }^{33}$ R. Ciesielska-Musameh: Literatura w nauczaniu cudzoziemców..., s. 7; T. Czerkies: Rozwijanie kompetencji literackiej — teksty prozatorskie na zajęciach języka polskiego jako obcego..., s. 260-262. W ramach Czytaj po polsku ukazało się opowiadanie Tokarczuk Szafa, przeznaczone do nauczania na poziomie zaawansowanym $(\mathrm{B} 2 / \mathrm{C} 1)$.

${ }^{34}$ L. Tanuszewska: Polskość czy światowość jako problemy przekładowe „Biegunów” Olgi Tokarczuk. W: Literatura polska w świecie. T. 5: Mapowanie, opisy, interpretacje. Red. R. Cudak. Uniwersytet Śląski-Wydawnictwo Gnome, Katowice 2014, s. 131.

35 O. Tokarczuk: Pasażer. W: Eadem: Opowiadania bizarne. Wydawnictwo Literackie, Kraków 2018. Wszystkie cytaty pochodzą z tego wydania. 
zawiera wiele elementów z zakresu zagadnień językowych realizowanych na poziomie A1: opis rodziny, dorastania, nazwy podstawowych emocji (strach). Opowiadanie cechuje się bardzo wyraźnym uniwersalizmem doświadczeń i realiów. Najważniejsze motywy to podróż, dzieciństwo i lęki głównego bohatera, który wspomina siebie jako małego chłopca. Miejsce akcji nie jest w tekście określone, a szkicowo zarysowana sytuacja życiowa tytułowego pasażera pozwala wyobrazić go sobie jako mieszkańca niemal dowolnego zakątka świata. Tytuł tekstu jest internacjonalizmem; w treści pojawia się jeszcze kilka innych internacjonalizmów oraz galicyzmy, na przykład wampir, koszmar.

Lektura utworu nie wymaga od czytelnika znajomości specyficznie polskiego kontekstu; tekst może być zrozumiały niemal pod każdą szerokością geograficzną. Opowiadanie można interpretować również jako zapis międzykulturowego spotkania: uzasadniona jest bowiem teza, że zajmujący sąsiednie fotele podczas międzykontynentalnego lotu nieznajomi pochodzą z różnych krajów i w rozmowie używają języka obcego dla jednej lub obydwu stron. Istnieje więc podobieństwo między sytuacją fabularną a lekcją, w ramach której uczący się czytają Pasażera. Tę koincydencję można wykorzystać w zadaniach komunikacyjnych i prosić studentów, by opowiadali sobie nawzajem historie czy wspomnienia tak, jakby byli obcymi sobie współpasażerami.

Ponieważ tekst został wybrany z myślą o rodzimych użytkownikach języka francuskiego, dużą zaletę stanowiło to, że jednym z najważniejszych motywów opowiadania był powracający zły sen — koszmar (fr. cauchemar). W pracy z grupą jednojęzyczną należy zwracać uwagę na słownictwo, które przez analogię ułatwi studentom zrozumienie sensu. W grupach międzynarodowych, często wyłonionych z podziałem na Słowian i nie-Słowian, można w podobny sposób oprzeć się na stosownym do sytuacji lingua franca — rosyjskim lub angielskim.

\section{Adresaci adaptacji}

W zależności od tego, jaki jest pierwszy (bądź wspólny) język uczących się polskiego, należy zaplanować parafrazę niezrozumiałych słów lub fragmentów. Odnoszenie się do właściwego zaplecza językowego odbiorców jest tym ważniejsze, im niższy jest poziom ich znajomości polszczyzny. Z tekstu należy wyeliminować „fałszywych przyjaciół” (o których, naturalnie, należy uczyć wcześnie, ale nie wówczas, kiedy i tak stawiamy studentów przed wyzwaniem) i w miarę możliwości wprowadzić wyrazy łatwo zrozumiałe — internacjonalizmy i zapożyczenia (lub po prostu słowa już znane). Trzeba też wziąć pod uwagę niezwiązane z biegłością językową zdolności poznawcze odbiorców, takie jak wiek. W szczególnych wypadkach, jeżeli planujemy połączyć lekturę utworu z omówieniem lub powtórzeniem konkretnego zagadnienia, należy 
zawczasu ustalić, na jakich strukturach i słowach czy typach wypowiedzi nam zależy (przykładowo w pracy z Pasażerem można utrwalać znajomość konstrukcji bać się + dopełniacz, języka emocji lub ćwiczyć umiejętność pisania wspomnienia $\mathrm{z}$ dzieciństwa). Odpowiednie fragmenty warto wyeksponować w parafrazie, być może kosztem trudniejszych i mniej przydatnych w danym kontekście passusów.

\section{Zabiegi adaptacyjne}

Jednym z głównych założeń proponowanej przeze mnie metody adaptacji jest zachowanie możliwie dużych fragmentów pierwotnego tekstu i ograniczenie ingerencji w oryginał do niezbędnych. Wybór właściwego utworu czyni to zadanie łatwiejszym niż w przypadku pracy z literaturą dawną bądź tekstem w inny sposób wykraczającym poza możliwości percepcyjne początkujących. Ważne jest również strategiczne użycie synonimów i powtórzeń oraz słów $\mathrm{z}$ jednej rodziny wyrazów, które, odpowiednio rozmieszczone w nowej wersji, będą służyły jako kolejne stopnie-przystanki na drodze do zrozumienia całości. Ostatnią sugestią, przydatną do przygotowania adaptacji dla uczących się na poziomie B1 i wyższym, jest równoległa lektura dwóch wersji tekstu: łatwiejszej, uproszczonej i trudniejszej, bliższej oryginałowi. Ćwiczenie można wykonywać indywidualnie lub w parach (zwłaszcza w grupach o nierównym poziomie), a jego celem jest, oprócz lepszego poznania tekstu, wzbogacanie słownictwa przez pracę z synonimami.

Przyjrzyjmy się zatem zastosowaniu zaproponowanych zasad adaptacji w praktyce. W tabeli 1 zaprezentowano zestawienie trzech wersji pierwszego akapitu Pasażera.

Tabela 1

Pasażer Olgi Tokarczuk -

zestawienie pierwszego akapitu tekstu oryginalnego

$\mathrm{z}$ adaptacjami tego fragmentu dla poziomów A2/B1 i A1/A2

\begin{tabular}{|c|c|c|}
\hline \multirow{2}{*}{ Tekst oryginalny } & \multicolumn{2}{|c|}{ Adaptacja } \\
\hline & poziom $\mathrm{A} 2 / \mathrm{B} 1$ & poziom A1/A2 \\
\hline $\begin{array}{l}\text { Pewien człowiek, który siedział } \\
\text { obok mnie podczas długiego } \\
\text { nocnego lotu przez ocean, opo- } \\
\text { wiedział mi o lękach, które } \\
\text { miewał nocą jako dziecko. Zwi- } \\
\text { dywał mu się wciąż ten sam } \\
\text { koszmar, a on krzyczał i w pani- } \\
\text { ce przywoływal rodziców. }\end{array}$ & $\begin{array}{l}\text { Pewien człowiek, który sie- } \\
\text { dział obok mnie podczas } \\
\text { długiego nocnego lotu przez } \\
\text { ocean, opowiedział mi, cze- } \\
\text { go bal się jako dziecko. Mial } \\
\text { wciąż ten sam koszmarny } \\
\text { sen, więc krzyczał i w panice } \\
\text { wołał rodziców. }\end{array}$ & $\begin{array}{l}\text { Mężczyzna, który siedział } \\
\text { obok mnie w samolocie } \\
\text { z Europy do Ameryki, opo- } \\
\text { wiedział mi, czego bał się } \\
\text { jako dziecko. Miał cały czas } \\
\text { ten sam koszmar; panikował } \\
\text { i prosił mamę i tatę, żeby byli } \\
\text { blisko. }\end{array}$ \\
\hline
\end{tabular}

W tabeli wyróżniono fragmenty różnicujące tekst oryginalny i adaptację dla poziomu A2/B1. 
Pierwszym etapem pracy nad adaptacją było zastąpienie trudnych słów z pierwowzoru zrozumiałymi synonimami (miewat lęki = bat się, zwidywat mu się koszmar $=$ miat koszmar, przywotywać $=$ wołać $). \mathrm{W}$ wersji dla poziomu A2/B1 wprowadzono dwie modyfikacje, których celem nie było uproszczenie tekstu, ale przypomnienie słowa sen (w zestawieniu z galicyzmem koszmar) i spójnika wynikowego więc. Następnie, aby uzyskać jeszcze łatwiejszy wariant - na poziom A1/A2, abstrakcyjny termin lot zamieniono na samolot, który łatwo pokazać na fotografii, a miejscownik internacjonalizmu panika zastąpiono czasownikiem odrzeczownikowym, w którym nie ma alternacji $k: c$. Wprowadzono też kolejne zmiany leksykalne.

Tabela 2

Pasażer Olgi Tokarczuk -

zestawienie drugiego akapitu tekstu oryginalnego

$\mathrm{z}$ adaptacjami tego fragmentu dla poziomów A2/B1 i A1/A2

\begin{tabular}{|c|c|c|}
\hline \multirow{2}{*}{ Tekst oryginalny } & \multicolumn{2}{|c|}{ Adaptacja } \\
\hline & poziom A2/B1 & poziom A1/A2 \\
\hline $\begin{array}{l}\text { Działo się to w długie wieczo- } \\
\text { ry - cichy, źle oświetlony czas } \\
\text { bez telewizyjnych ekranów (sły- } \\
\text { chać było co najwyżej szmer ra- } \\
\text { dia albo szelest ojcowskiej gaze- } \\
\text { ty) sprzyjał uprawie dziwnych } \\
\text { myśli. Ten człowiek pamiętał, że } \\
\text { już od podwieczorku zaczynał } \\
\text { się bać, mimo uspokajających } \\
\text { słów rodziców. }\end{array}$ & $\begin{array}{l}\text { To było zawsze w długie wie- } \\
\text { czory - cichy, ciemny czas } \\
\text { bez telewizyjnych ekranów } \\
\text { (słychać było tylko radio albo } \\
\text { szelest gazety) prowokowal } \\
\text { dziwne myśli. Ten człowiek } \\
\text { pamiętał, że już od podwie-- } \\
\text { czorku zaczynał się bać, mi- } \\
\text { mo uspokajających słów ro- } \\
\text { dziców. }\end{array}$ & $\begin{array}{l}\text { To było zawsze wieczorem } \\
\text { ciemny, cichy czas bez tele- } \\
\text { wizji (bo w tamtych czasach } \\
\text { były tylko gazety i radio) pro- } \\
\text { wokował dziwne wizje. Męż- } \\
\text { czyzna pamiętał, że zaczynał } \\
\text { się bać już po południu. }\end{array}$ \\
\hline
\end{tabular}

W tabeli wyróżniono fragmenty różnicujące tekst oryginalny i adaptację dla poziomu A2/B1.

W tym fragmencie komentarza wymaga pozostawienie w wersji na poziom A2/B1 imiesłowu uspokajający. Po pierwsze, w dalszej części tekstu czasownik uspokajać będzie niezbędny, nie ma więc sensu eliminować go tutaj. Po drugie, zasób leksykalny studenta obejmuje imiesłowy takie jak interesujacy, można więc objaśnić słowo uspokajający przez analogię, bez wchodzenia w szczegóły z zakresu gramatyki. Imiesłowy przymiotnikowe czynne i przysłówkowe współczesne nie muszą być bezwzględnie usuwane, jeżeli nie są liczne, pochodzą od znanych (lub koniecznych w danym utworze) czasowników i mogą być porównane do zrozumiałych imiesłowów, takich jak interesujacy, inspirujący, lub fraz (śpiewając $=k i e d y+$ osobowa forma śpiewać zależna od podmiotu). Formy gramatyczne takich imiesłowów są na tyle nieinwazyjne, że nie powinny negatywnie wpłynąć na rozumienie tekstu. Słowo szelest może być nowe, ale wyjątkowo łatwo wyjaśnić je na lekcji szeleszczeniem kartkami papieru.

Kolejny etap pracy nad adaptacją opowiadania zobrazowano w tabeli 3. 
Pasażer Olgi Tokarczuk zestawienie pierwszej połowy trzeciego akapitu tekstu oryginalnego $\mathrm{z}$ adaptacjami tego fragmentu dla poziomów A2/B1 i A1/A2

\begin{tabular}{|c|c|c|}
\hline \multirow{2}{*}{ Tekst oryginalny } & \multicolumn{2}{|c|}{ Adaptacja } \\
\hline & poziom $\mathrm{A} 2 / \mathrm{B} 1$ & poziom A1/A2 \\
\hline $\begin{array}{l}\text { Miał wtedy trzy, może cztery lata. } \\
\text { Mieszkał w ciemnym domu na pe- } \\
\text { ryferiach miasteczka, jego ojciec } \\
\text { był dyrektorem szkoły, zasadni- } \\
\text { czym, a nawet kostycznym, mat- } \\
\text { ka zaś pracowała w aptece, oto- } \\
\text { czona wiecznie chmurą zapachu } \\
\text { lekarstw. Miał też starszą siostrę, } \\
\text { lecz ona, w odróżnieniu od rodzi- } \\
\text { ców, nie próbowała mu pomóc. } \\
\text { Wręcz przeciwnie - z niezrozu- } \\
\text { miałą dla niego, nieukrywaną } \\
\text { radością przypominała mu już od } \\
\text { południa, że noc jest tuż-tuż. I gdy } \\
\text { nie było w pobliżu dorosłych, } \\
\text { karmiła go opowieściami o wam- } \\
\text { pirach, trupach powstających } \\
\text { z grobów i wszelkiego rodzaju } \\
\text { piekielnych istotach. }\end{array}$ & $\begin{array}{l}\text { Miał wtedy trzy, może czte- } \\
\text { ry lata. Mieszkał w ciem- } \\
\text { nym domu na peryferiach } \\
\text { miasteczka, jego ojciec był } \\
\text { dyrektorem szkoły i lubił } \\
\text { dyscyplinę. Matka pracowa- } \\
\text { ła w aptece i zawsze pach- } \\
\text { niała lekarstwami. Miał } \\
\text { też starszą siostrę, ale ona, } \\
\text { w odróżnieniu od rodziców, } \\
\text { nie próbowała mu pomóc. } \\
\text { Wręcz przeciwnie - z ra- } \\
\text { dością, której nie mógł zro- } \\
\text { zumieć, przypominała mu } \\
\text { już od południa, że noc jest } \\
\text { tuż-tuż. I gdy nie było w po- } \\
\text { bliżu dorosłych, opowiada-- } \\
\text { la mu historie o wampirach } \\
\text { i innych strasznych istotach. }\end{array}$ & $\begin{array}{l}\text { Miał trzy, może cztery lata. } \\
\text { Mieszkał w ciemnym domu } \\
\text { na peryferiach małego } \\
\text { miasta, jego ojciec był dy- } \\
\text { rektorem szkoły i lubił dy- } \\
\text { scyplinę. Matka pracowała } \\
\text { w aptece i zawsze pachniała } \\
\text { substancjami chemiczny- } \\
\text { mi. Miał też starszą siostrę, } \\
\text { ale ona, inaczej niż rodzice, } \\
\text { nigdy go nie uspokajała. } \\
\text { Nie! Już w południe z satys- } \\
\text { fakcją mówiła, że noc jest } \\
\text { blisko, i opowiadała historie } \\
\text { o wampirach. }\end{array}$ \\
\hline
\end{tabular}

W tabeli wyróżniono fragmenty różnicujące tekst oryginalny i adaptacje dla poziomów A2/B1 oraz A1/A2.

Jednym z rozwiązań dość często stosowanych w adaptacjach jest zamiana zdań złożonych na pojedyncze, ale — jak widać w tabeli 3 - nie zawsze jest to konieczne. Pozostawienie części zdań złożonych w ich oryginalnej wersji pozwala zachować naturalny rytm tekstu, zapobiega przerobieniu go na serię krótkich, jakby skandowanych wypowiedzeń. Jeżeli odpowiednio wytłumaczymy studentom, że przecinki również wprowadzają pauzy logiczne między częściami składowymi, nie powinni oni mieć problemu z czytaniem takich zdań, jak: Miał też starsza siostrę, ale ona, inaczej niż rodzice, nigdy go nie uspokajała.

W końcówce fragmentu zamieszczonego w tabeli 3 konieczne były dość daleko idące zmiany, między innymi dlatego, że słownictwo na określenie piekielnych istot nie wchodzi w skład najpotrzebniejszego zasobu leksykalnego. W przeznaczonej na lekcję dla dzieci (między ósmym a czternastym rokiem życia, znających język na bardzo różnym poziomie) adaptacji — zasadniczo identycznej z wersją na poziom A1/A2 — po słowach „historie o wampirach” dodałam jeszcze ,i zombie”. Nie sugeruję dopisywania do modyfikowanych utworów zbyt wiele od siebie (może to być ewentualnie zadanie dla studentów), 
ale drobne zmiany pobudzające ciekawość odbiorcy, zgodne z wymową i stylem tekstu, mogą okazać się przydatne.

Przygotowane przeze mnie adaptacje są nieco krótsze niż liczący 826 słów oryginał (A2/B1 - 702 słowa, A1/A2 - 531 słów). Uczący się języka polskiego jako obcego będzie musiał poświęcić na pracę z tym tekstem więcej czasu niż na naukę z podręcznikiem na danym poziomie zaawansowania, ale gdy porówna czytaną przez siebie wersję z pierwowzorem, przekona się, że rozumie frazy, a nawet pełne zdania $\mathrm{z}$ autentycznego utworu literackiego napisanego w języku, którego się uczy. Ponadto, jeśli odpowiednio dobierzemy tekst do adaptacji, w jej procesie możemy zachować wiele z charakteru oryginalnej narracji.

W moim odczuciu to, jak bardzo adaptacja odbiega od oryginalnego tekstu literackiego, łączy się z wielokrotnie podnoszonym w glottodydaktyce problemem dwóch sposobów obecności literatury na zajęciach językowych. Z jednej strony chodzi o posłużenie się tekstem w celu zaprezentowania lub utrwalenia zagadnień gramatycznych czy leksykalnych (to podejście jest zwane instrumentalnym, pragmatycznym bądź pretekstowym), z drugiej — o koncentrację na interpretacji, kontekstach i walorach utworu (opcja estetyczna). W pracach teoretycznych znajdziemy wskazania, jak połączyć obie metody pracy w celu osiągnięcia najlepszych efektów ${ }^{36}$. Na niskich poziomach zaawansowania nie ma możliwości przeprowadzenia pogłębionej dyskusji o artystycznej stronie tekstu, siłą rzeczy więc uwaga przesunie się w stronę ćwiczeń językowych (przykłady zagadnień językowych możliwych do poruszenia podczas pracy nad Pasażerem Tokarczuk wskazałam wcześniej). Jednocześnie zachowanie wielu cech oryginału pozwala mu zaistnieć na lekcji w bardziej autonomiczny sposób. Początkujący studenci mogą być również w stanie opowiedzieć o emocjach wywołanych przez opowiadanie bądź wybrany aspekt opisanych w nim wydarzeń, szczególnie jeśli wykorzystamy Pasażera, by wzbogacić słownictwo dotyczące stanów uczuciowych.

\section{Uwagi uzupełniające}

Do wymienionych już wskazówek mogących ułatwić opracowanie adaptacji tekstu literackiego z przeznaczeniem do nauczania języka polskiego jako obcego warto dodać następujące:

1. Prace nad przygotowaniem adaptacji należy zacząć od tekstu przeznaczonego dla studentów znających polszczyznę na najwyższym poziomie i stopniowo upraszczać kolejne wersje utworu. Im większą liczbę wariantów stworzymy, tym łatwiej będzie nam dobrać tekst dla różnych grup lub nawet studentów w obrębie jednej grupy. Porównywanie dwóch parafraz może być samo

\footnotetext{
${ }^{36}$ A. Seretny: Tekst literacki w dydaktyce języka polskiego jako obcego..., s. 294-296.
} 
w sobie ćwiczeniem. Nie tylko umożliwia poznawanie nowych synonimów, lecz także uczy, jak eksperymentować z internacjonalizmami i znaną sobie leksyką, by wyrażać bardziej złożone komunikaty, których na danym poziomie znajomości języka nie da się jeszcze ubrać w słowa.

2. W grupach, w których znajomość języka polskiego jest na bardzo wysokim poziomie, zwłaszcza wśród osób używających polszczyzny jako języka odziedziczonego, tworzenie adaptacji może być ćwiczeniem sprawdzającym świadomość językową. Zadaniem studentów może być sparafrazowanie trudnych elementów i, opcjonalnie, wyjaśnienie, dlaczego dana konstrukcja jest potencjalnie niezrozumiała (powodem może być na przykład występowanie w niej archaizmu, regionalizmu, terminu specjalistycznego, użycie slangu, rzadkiej formy gramatycznej).

3. Użycie w adaptacji podstawowego słownictwa oraz internacjonalizmów ma na celu uczynienie tekstu przystępnym dla odbiorcy nawet bez dodatkowej pomocy w postaci tłumaczeń na marginesach. Jednakże w razie potrzeby można takie tłumaczenia oczywiście dodać.

\section{Zakończenie}

W przedstawionym modelu adaptacji prozatorskiego tekstu literackiego do wykorzystania w nauczaniu języka polskiego jako obcego zasada oszczędnej ingerencji w tekst narzuca konieczność bardzo starannej selekcji oryginałów, która może wydawać się zbyt restrykcyjna i niepraktyczna. Jeżeli wybór utworu jest nadto utrudniony, można uwzględnić tylko niektóre ze wskazanych założeń (rezultatem będzie głębsza modyfikacja pierwowzoru). Ważne jest jednak, by nie rezygnować z autonomii literatury (parafraza powinna zachowywać przynajmniej elementy stylu i kompozycji tekstu prozatorskiego) ani autonomii odbiorcy. Tę drugą rozumiem tu jako wyposażenie początkującego studenta w wiedzę kulturową funkcjonalną w bieżącej debacie o literaturze i współtworzącą czytelniczą samodzielność odbiorcy. Chodzi zatem o zaznajomienie studentów $\mathrm{z}$ twórczością rozpoznawalnych i cenionych pisarzy w taki sposób, by uczący się mogli wypowiedzieć się o przeczytanym opowiadaniu lub fragmencie powieści w kontekście osobistych doświadczeń (na przykład emocji wywołanych lekturą, zbieżności przeżyć bohatera i własnych). Na niższych poziomach zaawansowania komunikaty formułowane przez studentów dotyczą przecież raczej ich samych i spraw bezpośrednio z nimi związanych niż odległych czasowo i światopoglądowo idei kultury, którą zaczęli poznawać. 


\section{Bibliografia}

Antologia bajek, baśni, legend i opowiadań z zadaniami. Wybór i oprac. A. Dunin-Dudkowska, A. Trześniewska-Nowak. Ilustracje na okładce i w tekście K. Wójcik. Wydawnictwo Uniwersytetu Marii Curie-Skłodowskiej, Lublin 2020.

Bednarek J., Swatek A.: Learn Polish Through Stories. Centrum Języków Obcych Inspiration, Wrocław 2018.

Ciesielska-Musameh R.: Literatura w nauczaniu cudzoziemców. Poradnik metodyczny. Część druga: Praca z tekstem literackim na zajęciach językowych. http://docplayer.pl/39455545-Literatura-w-nauczaniu-cudzoziemcow.html [dostęp: 3.02.2021].

Ciesielska-Musameh R., Guziuk-Świca B., Przechodzka G.: Z polskim w świat. Podręcznik do nauki języka polskiego jako obcego. Cz. 1: Poziom B1/B2. Wyd. 3. Wydawnictwo Uniwersytetu Marii Curie-Skłodowskiej, Lublin 2018.

Ciesielska-Musameh R., Guziuk-Świca B., Przechodzka G.: Z polskim w świat. Podręcznik do nauki języka polskiego jako obcego. Cz. 2: Poziom B1/B2. Wydawnictwo Uniwersytetu Marii Curie-Skłodowskiej, Lublin 2019.

Cudak R., Hajduk-Gawron W.: Problematyka adaptacji tekstu w edukacji literackiej cudzoziemców. W: Edukacja polonistyczna jako zobowiazanie: powszechność i elitarność polonistyki. Red. E. Jaskółowa et al., przy współpracy D. Jagodzińskiej i A. Zok-Smoły. T. 1. Wydawnictwo Uniwersytetu Śląskiego, Katowice 2016, s. 603-615.

Cyzman M.: Czego jeszcze nie wiemy o nauczaniu literatury polskiej? Tekst literacki na lekcji języka polskiego jako obcego. „Teraźniejszość - Człowiek — Edukacja” 2011, nr 4, s. 91-101.

Czerkies T.: Literackie lustro kultury. Literatura polska w ćwiczeniach dla obcokrajowców. Poziom B.1.2-C.1. Wydawnictwo Avalon, Kraków 2019.

Czerkies T.: Rozwijanie kompetencji literackiej - teksty prozatorskie na zajęciach języka polskiego jako obcego. W: W poszukiwaniu nowych rozwiazań. Dydaktyka języka polskiego jako obcego u progu XXI wieku. Red. W.T. Miodunka, A. Seretny. Wydawnictwo Uniwersytetu Jagiellońskiego, Kraków 2008, s. 255-263.

Czerkies T.: Tekst literacki w nauczaniu języka polskiego jako obcego (z elementami pedagogiki dyskursywnej). Księgarnia Akademicka, Kraków 2012.

Czerkies T.: Wykorzystanie tekstu literackiego na zajęciach języka polskiego jako obcego (motywy $i$ oczekiwania studentów). „Acta Universitatis Lodziensis. Kształcenie Polonistyczne Cudzoziemców" 2011, T. 18, s. 113-128. Pobrano z: https://dspace.uni.lodz.pl/xmlui/bitstream/handle/11089/9287/13-czerkies.pdf?sequence=1\&isAllowed=y [11.08.2021].

Czytaj po polsku. T. 1-13. Wydawnictwo Uniwersytetu Śląskiego, Katowice 2003-2020.

Frukacz K.: Reportaż literacki w glottodydaktyce polonistycznej - prolegomena. „Kwartalnik Polonicum" 2018, nr 28/29, s. 33-37.

Góralczyk-Mowczan P., Gaze M.: Błędy w adaptacjach tekstów literackich (na podstawie prac studentów specjalizacji Nauczanie Języka Polskiego jako Obcego). „Acta Universitatis Lodziensis. Kształcenie Polonistyczne Cudzoziemców” 2015, T. 22, s. 237-249. https://doi. org/10.18778/0860-6587.22.16.

Hajduk-Gawron W.: Arcydzieła literatury polskiej w praktyce glottodydaktycznej. Zaadaptować czytelnika i tekst. W: Adaptacje. [T.] 1: Język - literatura - sztuka. Red. W. Hajduk-Gawron, A. Madeja. [Biblioteka Postscriptum Polonistycznego. Nr 3]. Uniwersytet Śląski w Katowicach. Szkoła Języka i Kultury Polskiej. Katedra Międzynarodowych Studiów Polskich-Wydawnictwo Gnome, Katowice 2013, s. 353-365. 
Hajduk-Gawron W.: „Czytaj po polsku” — czytanie jako jedna z możliwości poszerzania kompetencji językowych [O serii „Czytaj po polsku”, Katowice 2003, 2004]. „Postscriptum” 2004, nr 1, s. 53-63. Pobrano z: https://bazhum.muzhp.pl/media/files/Postscriptum/Postscriptumr2004-t-n1(47)/Postscriptum-r2004-t-n1(47)-s53-63/Postscriptum-r2004-t-n1(47)-s53-63.pdf [11.08.2021].

Hajduk-Gawron W.: Lektura obowiazkowa i co ponadto? O obecności i nieobecności literatury polskiej poza krajem. W: Literatura polska $w$ świecie. Zagadnienia recepcji i odbioru. Red. R. Cudak. Wydawnictwo Gnome, Katowice 2006, s. 27-34.

Hajduk-Gawron W.: Przekłady literatury polskiej a dobór tekstów literackich w nauczaniu cudzoziemców. W: Sztuka czy rzemiosto? Nauczyć Polski i polskiego. Red. A. Achtelik, J. Tambor. Wyd. 2. Gnome - Wydawnictwa Naukowe i Artystyczne, Katowice 2009, s. 153-161.

Hiszpańska M.: Ola. Czytanka do nauki polskiego dla cudzoziemców na poziomie A2-B1. Studio Anatta, Warszawa 2019.

Jaskółowa E.: Poezja w nauczaniu języka polskiego jako obcego. W: Sztuka czy rzemiosło? Nauczyć Polski i polskiego. Red. A. Achtelik, J. Tambor. Wyd. 2. Gnome - Wydawnictwa Naukowe i Artystyczne, Katowice 2009, s. 125-140.

Jędryka B.K.: Walizka. Wydawnictwo Polish Point — Translator, Warszawa 2016.

Kubicka E., Cyzman M.: Seria „Czytaj po polsku”. Ikony literatury polskiej? W: Nowe perspektywy w nauczaniu języka polskiego jako obcego. 3. Red. E. Kubicka, A. Walkiewicz. Wydawnictwo Naukowe Uniwersytetu Mikołaja Kopernika, Torun 2015, s. 173-191.

Literatura i glottodydaktyka w praktyce. Tekst literacki w nauczaniu języka polskiego jako obcego. Red. A. Kwiatkowska, M. Válkova Maciejewska. Współpraca: K. Tyrakowska, I. Skrzypczak. Wydawnictwo „Poznańskie Studia Polonistyczne”, Poznań 2018.

Miodunka W. et al.: Nauczanie i promocja języka polskiego w świecie. Diagnoza, stan, perspektywy. Wydawnictwo Uniwersytetu Śląskiego, Katowice 2018.

Próchniak W.: Klucz do wierszy. Poezja w nauczaniu języka polskiego jako obcego. Wydawnictwo KUL, Lublin 2012.

Seretny A.: Tekst literacki $w$ dydaktyce języka polskiego jako obcego. Między percepcja a recepcja dzieła. W: Literatura polska w świecie. Zagadnienia recepcji i odbioru. Red. R. Cudak. Wydawnictwo Gnome, Katowice 2006, s. 292-306.

Stelmach A.: Czytaj krok po kroku. Proste historie. [T.] 1-3. Glossa, Polish Language School, Kraków 2018-2019.

Szałasta-Rogowska B.: Tekst literacki i malarski w nauczaniu cudzoziemców. Sposoby pracy na zajęciach lektoratowych. W: Sztuka czy rzemiosło? Nauczyć Polski i polskiego. Red. A. Achtelik, J. Tambor. Wyd. 2. Gnome - Wydawnictwa Naukowe i Artystyczne, Katowice 2009, s. $141-152$.

Świstowska M.: Obecność tekstów prozy polskiej po 1989 r. w nauczaniu języka polskiego jako obcego - realia, potrzeby, problem wyboru. „Acta Universitatis Lodziensis. Kształcenie Polonistyczne Cudzoziemców" 2010, T. 17, s. 425-432. Pobrano z: https://bazhum.muzhp.pl/ media/files/Acta_Universitatis_Lodziensis_Ksztalcenie_Polonistyczne_Cudzoziemcow/Acta Universitatis_Lodziensis_Ksztalcenie_Polonistyczne_Cudzoziemcow-r2010-t17/Acta_Universitatis_Lodziensis_Ksztalcenie_Polonistyczne_Cudzoziemcow-r2010-t17-s425-432/Acta Universitatis_Lodziensis_Ksztalcenie_Polonistyczne_Cudzoziemcow-r2010-t17-s425-432.pdf [11.08.2021].

Tanuszewska L.: Polskość czy światowość jako problemy przekładowe „Biegunów” Olgi Tokarczuk. W: Literatura polska w świecie. T. 5: Mapowanie, opisy, interpretacje. Red. R. Cudak. Uniwersytet Śląski-Wydawnictwo Gnome, Katowice 2014, s. 131-138.

Tokarczuk O.: Pasażer. W: Eadem: Opowiadania bizarne. Wydawnictwo Literackie, Kraków 2018, s. $5-9$. 
Tsai N.: Czarno na biatym. Poezja konkretna na zajęciach językowych. „Acta Universitatis Lodziensis. Kształcenie Polonistyczne Cudzoziemców" 2013, T. 20, s. 329-338. Pobrano z: https:// dspace.uni.lodz.pl/xmlui/handle/11089/4472 [11.08.2021].

Tsai N.: Utwór poetycki jako tekst glottodydaktyczny. Uniwersytet Łódzki. Wydział Filologiczny. Katedra Lingwistyki Stosowanej i Kulturowej. Łódź 2012. Niepublikowana rozprawa doktorska.

Turek W.P.: Utwory prozaiczne Stawomira Mrożka jako teksty wykorzystywane w nauczaniu gramatyki, stylistyki i kultury języka polskiego jako obcego. „Acta Universitatis Lodziensis. Kształcenie Polonistyczne Cudzoziemców" 2010, T. 17, s. 433-438. Pobrano z: https://dspace.uni.lodz. pl/xmlui/handle/11089/9604 [11.08.2021].

Wacławek M.: Od adaptacji do spektaklu na motywach dzieła $-z$ doświadczeń glottodydaktycznych. „Annales Universitatis Mariae Curie-Sklodowska. Sectio N - Educatio Nova” 2020, vol. 5, s. 409-425. https://doi.org/10.17951/en.2020.5.409-425.

Zarych E.: Język kluczem do kraju. Język polski dla obcokrajowców. Poziom C1/C2. Nowela - Portal romanisty, Poznań 2018.

Zarych E.: Przejdź na wyższy poziom. Język polski dla obcokrajowców. Poziom B2/C1. Wydawnictwo Nowela, Poznań 2014.

Żeromski S.: Siłaczka. Rozdziobia nas kruki, wrony... [Opowiedziała i oprac. A. Szol. Red. nauk. R. Cudak, W. Hajduk-Gawron, J. Tambor]. Wyd. 3. [Czytaj po polsku. T. 4]. Wydawnictwo Uniwersytetu Śląskiego, Katowice 2013.

Žák-Caplot K.: Legendy Starego Miasta w Warszawie. Wybór tekstów do nauki języka polskiego jako obcego z ćwiczeniami. Muzeum Warszawy, Warszawa 2019. 